Research Article

\title{
Sustainable Development Goals and Community Service Organizations Working for Children in Education in Sudan
}

\author{
Azza $O$ Abdelmoneium-PhD. \\ Senior Lead Researcher Doha International Family Institute PO box 92745 Doha, Qatar
}

\begin{abstract}
The sustainable development goals (SDGs) working towards the 2030 agenda are intergovernmental set of aspirations goals outlining 17 development goals and it has associated 169 targets. Among them is education, which ensures inclusive and equitable quality education, and promote lifelong learning opportunities. Civil society organizations (CSO), plays an important role in achieving SDG in education. The purpose of this paper is to discuss the problems encountered by CSO in providing basic education in Sudan for poor children, in particular, gender equality in education, child friendly schools to ensure quality in education.

This paper used empirical data, which was part of a PhD dissertation on displaced children and CSO. Interviews and focus groups discussions conducted with children age 10-18 and with four CSO key managers. Interviews conducted with a sample of 129 poor children in Khartoum.

The paper will present a case study from Sudan and the voices of the children in access to education and the role of CSO in providing gender equality in education. I argue that if CSO works with and for poor children in education, and have a sound strategy to gender equality in education; SDGs in education by 2030 might achieve. The paper will end with recommendations for access to education and gender equality in education. CSO should work with and for the poor children in education and should strive towards achieving gender equality in education.
\end{abstract}

Key Words: Education, Children, Sustainable Development Goals, Community Service Organizations, Gender, Equality.

\section{INTRODUCTION}

Education in the Arab countries remains a challenge in the region. Although some countries have made some progress but still participation levels are low. Children in the Arab region still are out of primary school. The region is still home to almost 5 million children out of school age and the provision of good quality education needs particular attention. The region has shown imbalances in the way many education systems are developing which created disparities (UNESCO 2013).

Sustainable development goals presents a historic opportunity to advance the right and well-being of children especially the most disadvantaged and aims at securing a healthy and educated planet for today's children and future generations. The SDGs has 17 goals with 169 targets. Education in the SDGs is goal number 4, which ensures that by 2030 "all girls and boys complete free, equitable and quality primary and secondary education leading to relevant and goal 4 effective learning outcomes. To eliminate gender disparities in education and ensure equal access to all levels of education and vocational training for the vulnerable including persons with disabilities, indigenous people and children in vulnerable situations ..." (UN 2016:2). Thus, to implement this goal, government, public sector, private and civil society

organizations can play a role in implementing education.

In this paper, the role of one of the civil society organizations in how to implement goal number 4 and the problems they

4416 encounter in implementing education services is discussed. The paper will focus on CSO who are providing primary educational services to indigenous vulnerable children in Arab countries, taking Sudan as a case study. Therefore, the objective of this paper is to describe and address the work and challenges that civil society face in implementing quality education with gender equality for poor internally displaced children living in Khartoum-Sudan. It will recommend creative solutions for CSO to consider as interventions in education and gender equality. Key issues addressed include: 1) CSO 2) gender equality in education, 3) teacher education, 4) child friendly Schools 4) conclusion and recommendations

\section{METHODOLOGY}

The methodology for this paper was based on a fieldwork carried out on consecutive periods from 2004-2012 in four main camps in the urban and peri urban areas of the three main cities in Sudan: Khartoum, Omdurman, and Khartoum North. Each camp contained more than 100,000 persons. The findings presented in this paper are on one camp namely Mayo camp. The findings based from a wider research on one of the civil organization working for children in education in Sudan.

Various methods used in the research, among them interviews and focused group discussion. Interviews conducted with the children age 10-18. A sample of 129 children from the camps was selected. 


\section{Azza O Abdelmoneium / Sustainable Development Goals and Community Service Organizations Working for Children in Education in Sudan}

Focused group discussions and informal gatherings with children were carried out to get an in depth view of the situation. Topics discussed concerned health and education. I conducted 30 focused group discussions from the four areas consisting of 125 boys and 166 girls making a total of 291 informants. The number of children in each discussion group ranged from five to 12 children.

\section{CIVIL SOCIETY ORGANIZATIONS (CSOs)}

Civil society organizations play an important role in providing educational services to the children. Civil society "includes the family and the private sphere, referred to as the "third sector" of society, distinct from government and business" (Wikipedia 2016). Dictionary.com's 21st Century Lexicon defines civil society as 1) the aggregate of non-governmental organizations and institutions that manifest interests and will of citizens or 2) individuals and organizations in a society, which are independent of the government (Wikipedia 2016).

CSO encompass a wide range of organizations that may differ in objectives, membership and organizational structure. Among them are charitable organizations, women's organizations, self-help groups and religious organizations. They have in common that they are distinct from the state, i.e. they do not form part of the state structure (Abdelmoneium 2008). The term CSO in this paper refers to organizations whose activities are directed to the initiation or supporting of development processes, especially in the interest of the poor, and in particular, poor marginalized children.

There has been a worldwide growth in the number, size and operations of CSOs in the last two decades. Their role redefined within the development discourse. Their methods, approaches and strategies have been praised and criticized (see Clark 1991, Van Heemest 1982; Wils 1994; Korten 1986; Hulme and Edwards 1992 \&1997 to mention a few). Nevertheless, the impact of the work of the NGOs on the beneficiaries and how the beneficiaries view the work of CSOs has not yet received sufficient attention.

In this paper, I define CSOs as non-profit organizations working for the people to satisfy Their basic needs and rights. Their clients in this case are mostly the war affected and displaced because of drought, desertification and famine. CSOs are not engaged in commercial business or profit making; and their political objective is neither clear nor dominant.

\section{ROLE OF CSOS IN SUDAN:}

Several studies discussed and contested the changing roles and types of NGOs (see Uphoff 1993; Fowler 1988; Farrington and Babbington 1993; Bratton 1990). Korten (1986:6)distinguishes three distinctive stages or generation in NGOs dealing in relief or development programmes.

The first generation focuses on relief and welfare, relying on private contributions to deliver welfare services to the poor. Relief here means essential response to emergencies. However, from a development perspective, relief and welfare approaches offer little more than temporary alleviation of the symptoms of underdevelopment. The second generation focuses on small-scale self-reliant local development: this means sustainable improvements in the lives of the poor, depending on their capacity to meet their own needs with the resources they control.

The third generation focuses on sustainable system development: in this generation, efforts of the NGOs, both public and private in collaboration with the government, unite to work on the development of more supportive policies, programmes and institutions so that the poor can act on their own and be self-reliant in development. This generation involves an indefinite period and the capacity required by NGOs is strategic management backed by social and institutional analysis, plus facilitation and coalition building. In Sudan, the majority of the civil society work in the first and second-generation fields. The case studies in this paper focus mainly on the first and second type of civil society providing services to the poor.

Civil society in Sudan assist in the educational and health interventions, as part of the development of the country, but they do not fully engage in the empowerment of the poor. CSOs in Sudan that focus on sustainable system development are very few. This is because sustainable development requires an indefinite period and NGOs in Sudan are limited in funds and duration of the projects. The most they can do is to assist in constructing schools or health centers, and provide some assistance. However, only building schools or health centers do not achieve sustainable development. The ability of the people to be self-reliant and to act on their own is one of the important elements in alternative development strategies; but the state can be an obstacle for NGOs' engagement in sustainable development (Abdelmoneium, 2008). This is what will be discussed in the forthcoming paragraphs.

\section{CSO AND INTERNALLY DISPLACED CHILDREN IN KHARTOUM-CASE STUDY}

Sudan has a population of 39.1 million, increasing at a rate of 2.64\% (World Population Review 2014:1). The population of Khartoum in 2015 was 5,129; half of these are IDPs from Darfur, South Sudan, Nuba Mountains, South Kordofan and Blue Nile residing in four main camps and 30 official squatter's areas (World Fact book 2015, Lyytinen 2009). An estimated 4.367 million people have been displaced; half of them are living in Khartoum, half of them are children under 18 years (World Fact Book, 2015: 12).

Khartoum is the most affected state as it is the principal recipient of increasing numbers of displaced persons who have been arriving at a growing rate, from $14 \%$ in 1956 to $42 \%$ of the population in 1993. Women are estimated at one third and children under five constitute nearly 20 per cent of the IDP population in Khartoum, along with a significant number of old men and only a minority of young men capable of work. The average household consists of 6-7 persons. Approximately $15 \%$ originate from Darfur and the rest are 


\section{Azza O Abdelmoneium / Sustainable Development Goals and Community Service Organizations Working for Children in Education in Sudan}

from South Sudan, Blue Nile and South Kordofan (Lyytinen, 2009).

Displaced children are vulnerable and face many challenges in meeting their basic needs. Although children should be active agents in meeting their rights, in Sudan voices of children are not heard and their educational rights are not fully met. However, many displaced children do not go to school. CSOs play an important role in facilitating education to the children, but do they implement this service as per the SDGs and gender equality? In this paper, I argue on whether the CSO working in Sudan are providing education in a gender sensitive approach and how they can work with a gender equality approach in order to meet the SDG and the education goal. Policy and practice of one of the CSO working on education for displaced children will be used as a case study.

\section{THE POLICY OF THE CSO}

An international organisation working to recognise the nature and needs of childhood and aims to enable children to live a healthy, secure life. It started working in Sudan in the 1950s, aiming to promote sustainable development, provide humanitarian assistance and health care provision. It targets internally displaced persons, disaster victims, women and children. It has the capacity to develop the community through training and needs assessment. Its aim is that children, their families and their communities should have the resources and support they need to allow them to build their own future. Childhood should be valued in its own right and children's contribution to build a better world for us all is recognized and fostered.

The mission of the organization is to ensure that children everywhere protected from harm and given the best start in life. It aims to work with children, their families and their communities in order to build on their capacities to help themselves and take charge of their own lives, to listen to children and to ensure that their voices heard in decisions that affect them. They work in particular with children and young people to demonstrate and promote their values, particularly the rights of the child.

Clearly, the organisation is developing a rights based approach and working in developing the needs of the children, but are such aims met in practice? Are they working in a gender sensitive approach when providing education?

\section{KHARTOUM BASIC EDUCATION PROJECT FOR DISPALCED CHILDREN}

Since 1989, the organization has been running a basic education project for displaced children in Khartoum. The initial support was the construction or reconstruction of school facilities using local materials, the provision of educational materials and other services such as water and sanitation and teacher's incentives. The goal of the project is to safe guard the right to quality, inclusive basic education for more than 12,000 displaced children living in Khartoum. The project objectives are to increase the participation rates in basic education of girls and working children residing in IDP camps. To improve the quality of teaching and learning and to enhance the role-played by students and members of the local community in decision-making and management in their school. However, within each objective there are measures to safeguard the right to education. I will refer to these later in the paper when discussing gender. The focus of the project is to support the school and train the teachers.

I chose to examine the educational services provided at Mayo camp where the organisation supports five schools. My case study is Rahma School in Mayo camp.

\section{RAHMA SCHOOL IN MAYO CAMP}

Rahma School is located in the unplanned Mandela area. Mandela is one of the most remote areas in Mayo camp with a population of almost 30,000. It is located in an unplanned area where the conditions reveal its poverty and scarcity of resources. There is no electricity in the area and no water and people depend on buying water from the donkey carts.

Rahma (meaning mercy) School is made of brick-built. It is located in the centre of Mandela area and covers almost one hectare, with five main rooms of brick and three rooms of straw. In the three straw classrooms, for grades one to three, most of the children sit on the ground. Grades four to eight are in well-built rooms but the seating is inadequate for the number of students. One room is for the teachers.

There are seventeen male teachers and four female, all from the South, with the exception of one female teacher from the west of Sudan. Most of the teachers live in the same community, eight of them have salaries from the Ministry of Education, but the others are paid in incentives by the organisation, which means that, unlike salaried staff, they are unable to claim benefits such as pension for the time worked at the school. Most of the teachers have secondary certificates, but no extensive teacher training. The organization conducted a nine-month in-service teacher-training course designed for unqualified teachers and focussing on the methodology and promotion of child-centred learning approaches by Sudan Open Learning Organization, but only three teachers from Rahma School were selected for the course.

In 2008, Rahma School enrolled 1220 boys and 408 girls between the ages of seven and eighteen. Boys make up more than $75 \%$ of the school population. Although the project proposal states that the children in the organisation-supported schools are from seven to fifteen, I found out that many children are over fifteen. They prefer to enrol in the school, rather than attending the adolescent classes that take place in the evening.

Children in the school are from different tribes, mostly from the Southern Dinka, Nuer and Shiluk tribes, but there are few from the west of Sudan. In past years, the Organization helped the students with uniforms and educational materials, but since 1998, this has ceased. The parent council decided that children have to pay school registration fees each year amounting to 35 


\section{Azza O Abdelmoneium / Sustainable Development Goals and Community Service Organizations Working for Children in Education in Sudan}

thousand dinars equivalent to 13 US dollars per child where the average monthly wage per person varies according to the occupations. Many displaced people combine occupations and work for longer hours because of the low rates of pay. Wages varies from 15 US dollars to 125 US dollars per month, but if compared these wages to the cost of living for a family of five, a minimum expenditure on food, water and fuel would be 45 US Dollars. This is excluding the transport costs, costs of clothing, taxes, health care and school fees. This is in addition to the costs of books and examination fees that vary from class to class. Each book costs 500-700 Dinars equivalent to 2.5-3.5 US Dollars, but the organization negotiated with the Ministry of Education for a subsidized rate for books. They rent the books to the students and at the end of the year, they return them to school. Books do not arrive at the school on time, sometimes-arriving half way through the school year. In grade eight, the students pay examination fees equivalent to 25 US Dollars. This extra expense is because they then go to senior school. This extra cost is a big problem to many children, as they do not know how to afford such extra costs.

\section{GENDER IN PRACTICE}

How does the programme work in practice and does it meets the needs of the children and adolescents in the camp and can it bring about changes in the gender gap?

\section{A.The Case of Teachers and Children}

In this case, I will focus on four main issues that came out from my research in relation to gender. Those issues are teacher education, space, attention and involvement in family matters. The later issue will be described under the case of Nagla. In every class in Rahma School at Mayo camp, the boys sit at the back and the girls sit in the front. The older boys sit at the back of the class while the younger ones in front of them. The number of boys is always greater than that of girls. The space provided for the girls is insufficient and uncomfortable for the girls to express themselves freely. This is because the girls given the first four benches while the boys are distributed among the remaining benches because their number exceeds the girls. This resulted in a crowded and uncomfortable seating ranging between 6-8 girls to sit in one bench.

The children in Rahma School and particularly the girls were sometimes angry about this inequality and fight against it. Athena a 10-year girl was angry and said, "I do not like the behaviour of the teachers to us girls, they always tell us to squeeze and sit together while there is space at the back. They think that we argue with the boys but always the teachers give boys better chances than us (the girls), this is not fair and equal. Even in the playground the teachers let the boys play in the big yard alone while us, the girls, are not allowed to play with them or given enough space to play with other girls".

The teachers segregate boys and girls in recreational activities. During the breakfast time, boys play football while girls play hide and seek or skipping. In the recreational classes, boys and girls are treated differently. The teachers select drama for the boys and singing for the girls, saying that boys are better at drama than the girls are, and girls are better singers. Fatima a 13-year-old girl from the Nuba wanted to join the drama lesson but the teacher told her that she better do singing. She was sad for a few days because she was not given the chance to participate in what she wanted. Obviously, the space given to boys is more than girls in relation to freedom of choice and expression.

Several times the teachers give the boys the chance to answer before the girls. The boys received more attention and were frequently asked if they understood the lesson. In the absence of the teacher from the class, always a boy appointed monitor. Girls are never appointed monitors saying that they have less authority and power than boys do to control the behaviour of the class. Asya a fifteen year old girl said, "the teachers always chooses the boys and not the girls, once I raised my hand to be a monitor but the teachers said that girls do not know how to control a class of 70 students. I felt that I have less power and am worth nothing compared to the boys". Attention also given to the younger boys than the elder ones, saying that elder boys are more capable to understand the lesson and find their own ways better than younger boys. This made elder boys uninterested in attending classes as John a 17 year old boy said that he skips classes because he find the lessons difficult for him and several times he requested assistance from the teachers but his request was not fully achieved with full attention.

\section{B.The Case of Nagla}

Gender plays a role in the access to education. Families prefer to educate boys rather than girls. Nagla is a 13-year-old girl from the Nuba tribe. She did not know how to read and write until the age of 11. This is because her other boys brothers were given a chance to go to school by her parents. Her parents told her that it is not necessary to go to school from an early age. At the age of 11 after her elder brothers were mature enough to work and pay for themselves she was given the opportunity to go to school. Moreover, she has to work after school to support herself. Her father discourages her in continuing education; he does not want to support her financially. She works in the afternoon in front of their house selling sweets or donuts, with the help from her mother. After all that, she is scared that her father might make her marry if someone proposes. She wants to finish school and be a doctor but she is terrified of the hidden future and her father who will force her into marrying. She said, "my parents told me that if someone proposed to me, I have to marry him. I cannot say no to them and I have to obey what they say, although I like school and want to finish it. They said that now I am a grown up girl, I can be responsible of my own house, and I have to marry. My parents keep telling me that marriage is better for the girls. It protects them from sexual harassment by boys and the place of a girl is always with her husband and her own children. But until now no one proposed and I hope that no one does because I want to finish school".

\section{ANALYSIS}


The description and findings above shows that there is a discrepancy between stated policy and implementation in terms of gender. The main goals and aims of the organisation mention they apply gender and education and take into consideration to provide equality in education because it abides to the rights based approach and CRC, which includes gender as an important factor in meeting children's rights.

At the project proposal level, gender was a criterion for the selection of the target group and the specification of the objectives. Girls explicitly targeted to make sure that they followed education, and explicit objectives were to increase the educational participation of girls and the reduction of the higher dropout rate of girls. This means that both the general and the project policies of the organisation that provide education to displaced children do provide statements on gender, that existing gender inequalities be recognised, and plans made to redress this undesirable situation. Project proposals do propose a gender-based selection of the target group, by making sure that, the number of girls attending is equal to that of boys, but they not go beyond the aim to equalize numbers, because they do not state an organisational aim to contribute to the struggle for gender equality.

Practically, gender in the project objectives gives special emphasis to the increase in participation for girls in basic education. This is not occurring in practice in Rahma School. Looking at the gender aspect in the activities, the gender inequality between boys and girls were hardly questioned let alone reached to. The number of boys is more than half the number of girls, which diminishes the chance for the girls to participate and engage in education. Especially in the senior classes the gender gap increases, the number of girls becomes less. In grade eight, there were 12 girls and 55 boys. This indicates the unequal opportunities of girls in starting and finishing school, because of cultural beliefs about education for girls, early drop out due to marriage, lack of finances, the need to work for the family and lack of female role models in the teaching staff. The gender gap not easily closed without extra effort and without specifically targeting girls.

As said above, it is not sufficient to give preference to girls at the gate. Doing justice to gender is more than obtaining a numerical balance of boys and girls, however important that is. A gender sensitive approach has to take note of the power differences between men and women, boys and girls, and how these are being constructed and imposed through a wide variety of social and cultural processes, including the composition of the curriculum, the pedagogical style, the attitudes of the teachers, parents and society, the spatial arrangements, or the expectations about the educational and work career of the pupils.

The composition of the curriculum plays an important role in increasing the demand of girls to schools. The way the curriculum is set, helps the girls, families and teachers to view education and the content of the curriculum. This influenced by gender equality in wider society. For example in some societies, it assumed that girls are not good at mathematics and that boys cannot learn about the care of young children. Assumptions like these and the teaching that accompanies them, may reinforce gender inequalities. Therefore, amending the curriculum to make it gender sensitive is important to increase the enrollment of girls to schools (Oxfam 2007:28).

Another objective in the project is to improve the quality of teaching and learning. This makes me look at the power relations and empowerment in gender. Teachers are following a teacher-centred monologue method, which only concentrates, on the teacher without participation from the students. The method of teaching does not encourage girls and boys to engage in discussions with the teachers. The segregation of boys and girls in the classroom is an indication that creates a difference in the personalities between the boys and the girls. This segregation in itself can be a barrier for girls to further into education. The organisation includes gender in their policies, but their actual practice hinders the full empowerment of children, and female children in particular. The exercise of power by the teachers over the children in Rahma School does not allow children to emancipate or engage in decision-making. The above cases reveal how boys and girls are segregated, how they seated and treated hierarchically, and how the teachers make decisions for them. The teachers reinforce existing social inequalities between the boys and girls, by appointing boys are their representatives, and by not dealing with harmful cultural traditions, that hampers the school career of girls. The teachers profit from their 'power over' the students to impose genderinsensitive education.

The case cited shows clearly that it is difficult for girls to engage in discussion and receive attention from the teachers. Although in the classroom they sit in the front, the number of boys is more and the teachers gives more preference to boys. Hence, there is discrimination in the teaching approach by the teachers. By giving children a chance to participate, "they learn to express their own needs, consider those of others, and develop skills of co-operation, negotiation and problem solving. When their ideas and capabilities respected, children's confidence and self-esteem grow. Participation develops children's sense that decisions are their own, and increases their commitment to making them work" (Miller 1997:5). However, girls not treated as persons in their own right, they not given the chance to participate and express their own needs.

The development of the curriculum to address gender inequality cannot happen in isolation from other aspects such as ways of teaching, learning and interaction within the classroom. Equity will not be achieved if girls are discouraged from speaking, if boys absorb a disproportionate amount of the teacher's energy, or if physical environment does not support equal access to education (Oxfam 2007:29). This is true in the cases above, where class is crowded and girls not seated well, also when the girls were not giving a choice to select what they want to play, all are issues, which discourages girls from going to school. In particular, those girls in the 
school have different traditions and norms and Khartoum is a new area to them.

Girls encounter learning problems because of the low expectations of teachers regarding their intellectual abilities, which coupled with a low level of feedback from the teachers. In addition, girl's low expectations of herself also contribute to the problem, as does a lack of female teachers in high status subjects such as maths and science. Teachers and style of teaching can make a difference inside the school. If teachers are seen as facilitators of learning rather than as delivering knowledge then they are obliged to ensure that all children learn (Oxfam 2007:30).

In the sphere of gender equality, which means, "that boys and girls would experience the same advantages or disadvantages in educational access, treatment and outcome. The achievement of full gender equality in education would imply: equality in opportunities, in the sense that boys and girls offered the same chances to access school, that is: teacher, parent and society have no gender-biased attitudes in this respect. Equality in learning process, that is, girls and boys receive the same treatment and attention, follow the same curricula, enjoy teaching methods and teaching tools free of stereotypes and gender bias, are offered academic orientation and counselling not affected by gender biases, profit from the same quantity and quality of appropriate educational infrastructure. Children must have equality of outcome that is, learning achievements; length of school careers, academic qualifications and diplomas would not differ by gender. Finally equality of external results, that is, job opportunities, the time needed to find a job after leaving full-time education, the earnings of men and women with similar qualifications and experience, etc. would all be equal." (UNESCO 2003:44). Nevertheless, from the cited case studies, there is a clear indication of gender inequality in the teaching and treatment of girls and boys.

Another assessment for gender was analysing the gender differences in the participation and access to education by the children. The idea that girls punished because they are not wearing their school dress while boys do not is in itself segregation and partition that gives boys more superiority towards the girls. The segregation of girls and boys in the playground and in the classroom hinder the attainment of children receiving the same treatment, attention and teaching method, free of stereotypes and gender bias. The attitudes of the staff, the method of teaching gives an indication that there is inequality in the learning process, hence, how gender equality attained when the teachers themselves discriminate between boys and girls in the teaching method.

The problem is that gender biased and stereotyped thinking originates in society. In the community and society, children's participation in decision-making is almost nil. It is possible that children participate in decision making in the household when they are breadwinner and most senior male in the household since the family is dependent on their income and the father or another adult male authority died or is absent: the influence of girls is definitely less than that of third brothers. The organisation do not allow either girls or boys to participate in any of the projects that concern them, but merely treat them as obedient recipient of aid, rather than active agents in their own development.

CSO do not purposely discriminate between boys and girls, and even target girls in order to redress imbalances, but this is not to say that each child's access to the services was equal. The gendered division of productive and reproductive labour between boys and girls influenced their relative access to education. In the camps, both boys and girls are active in the productive and reproductive sphere in order to support themselves and their families. The case of Nagla stated above clearly shows that there is gender bias in the family between her and her brothers, in addition for her to work to support herself. The father gives the opportunity to the boys and excludes her from education until the age of 11. After all that, she has to work in order to finance her own education. Moreover, girls like Nagla and others in Mayo camp encounter problems within their families who may force them to marry at an earlier age.

The role of the Organisation as stated in their policy is to work towards the implementation of the rights of the children, with and for them. Also to ensure a better world for children and satisfy their needs. However, the organisation is not implementing projects that aware children of their rights and needs. The role of the organisation and the trained teachers in having equal education in gender can be more effective if the teachers follow a right-based approach and a more gender sensitive approach in education. The environment in which the children raised is a complex one and hinders their personality and development skills in particular the girls. They live in a complicated world mixed with traditional and cultural beliefs that affect any development. The organisation advocates for children's education but still children encounter many difficulties in meeting their education and the organisation is not addressing the root cause of the problem. Children affected by culture, tradition, standards and practices that influence their rights and overrule their access to education. Segregating boys and girls by imposing cultural beliefs from a young age will affect the personality of the growing child giving girls a sense of inferiority and boys of superiority, resulting in gender inequality.

The lack of awareness of the importance of education to children and in particular girls leads to the drop out of the girls before school is finished. Many other girls start school late because of family social pressure and preference of boys to girls. Instead of awareness of the importance of education to the girls by the teachers, the teachers continue to segregate between the genders. The situation is worsened when age differences between elder girls and younger ones are neglected and the same for the boys.

This is due to the teachers' lack of awareness of the different needs of girls and boys and of the various ages. The needs of adolescents are different from those of children of twelve or 
thirteen. Adolescence is a critical age and a step towards adulthood. Adolescents may need more attention, care and respect than the younger children in the class may. They need to express themselves freely, to give the chance to speak and air their views. They need to learn to take their own decisions. When teachers neglect these needs, adolescent confidence is undermined and they feel inferior in the class. The other side of the coin is that children of twelve or thirteen can feel that their skills and abilities are less than those of the older children in the class are because they sit at the front and the teacher concentrates on them. Such situations can create a feeling of inferiority, as most children in the camp work from the age of five or six. By twelve or thirteen, they frequently support themselves and their families and are mature enough to take care of themselves and make their own choices.

All these issues are in conflict with the policy of the organisation that stated adherence to the education and gender equality. It is clear that there are still discrepancies between the policy and the practical implementation of the organisation's activities.

\section{CONCLUSION AND RECOMMENDATIONS}

This paper has presented a few of the challenges that one of the CSO face in providing education and ensuring gender equality. The problem is that similar organisations can fall into the same problem. CSO in Sudan does not start with a platform for assessing the situation before implementation. CSO implement the project but the monitoring and enforcement of strategies in Sudan falls far short. Therefore, the following recommendation can have an impact on the education and gender equality:

1. CSO in Sudan need to be specialised in how to implement education and how to ensure that there is gender equality in education. I would recommend that the CSO to conduct situation analysis before implementing the project, most of the CSO in Sudan work as complementary to the government. In cases such as displacement, the government would request from the CSO to step in and provide assistance in health, shelter, food and education. Therefore, CSO step in without proper investigation or research in the area and the community that needs assistance. In conducting a situation analysis, most importantly is the participation of the children and hearing their voices in what they know and need in education. Most of the CSO do not work with the children, but work with their parents or guardians and this will not generate effective results in the long term.

2. CSO should assess the school looking to ensure a gender equity programme. This might be through looking at perceptions of masculinity and femininity of the children at school. The CSO need to know whether gender is a term that the school wants and expects of its teachers, CSO can initiate strategies and projects to develop a program for gender equality. The problem as mentioned earlier is that most CSO in Sudan are relief or rehabilitation.

3. CSO can also work on the curriculum content by working with the children. Girls and boys need to be involved with the CSO to consider what they want to learn and what the school offers them. In addition to learning materials, which are often images in textbooks, is there portrayal of gendered images. It is important, as we need a more sophisticated understanding of and response to how children learn about gender from textbooks.

4.CSO need also to look at the language of instruction and literacy, the children who are geographically or culturally marginalised might find that they are taught in a different language, therefore, CSO need to understand the language of instruction is it empowering or disabling girls or boys differently. These are issues, which can have an impact on the sustainability of the project endorsed within the curriculum of the school including gender approaches.

5. Community awareness of the importance of education in particular of girls by the state and CSO is necessary. The CSO can play a major role in community awareness to the children and their guardians. This can be through education session, club sessions, and friendly home visit, using simple tools to encourage guardians to allow their children to school.

6. CSO can adopt the child friendly education developed by UNICEF because it deals directly with education and equity. It is child centred, and child seeking. Child cantered educations "acts in the best interest of the child and leading to the realisation of the child's full potential. It includes health, nutritional status, and well-being and about what happens to children in their families and communities before they enter school and after they leave it" (UNICEF 2013:15). Child seeking ensures that children have an equal chance to enter the education system, the system proactively looks for children who are not participating and makes sure they become enrolled (UNICEF 2013:16). The method and style of teaching by using a child friendly education will develop and improve by using participatory and interactive approaches between the students and the teachers.

7. The CSO can also follow a child readiness approach, which reflects the interaction between the child, the school and the family. The dimensions of school readiness focus on children's learning and development, ready schools focus on the school environment along with practices and support smooth transition for children into primary schools, and ready families who focus on parental and caregiver attitudes and involvement in their children's learning and development transition to school. (UNICEF 2012:11). The three dimensions work together to ensure an effective enhancement to education.

8. CSO need to work with a child-to-child approach, which is a promising approach to providing cost effective and efficient interventions in education especially for, deprived marginalised populations. Other children, playmates, older siblings, that they interact daily, influence young children. By building on this system, it can affect school readiness for other children and enrolment. This approach will increase both girls 
and boys on time enrolment and ensure that children arrive at school with strong foundation in language, early literacy as well as emotional and social skills for learning. It can decrease dropout rates and enhance school performance (UNICEF 2013:5-7).

CSOs need to integrate and develop strategies to address the gender equality in education among marginalized deprived populations such as the displaced and to do successfully by 2030. Such a strategy must identify a pathway too many more schools, more access for poor students, more and bettertrained teachers, and of course and expanded education budget. A successful strategy will have to deploy every innovative technique at hand, such as a vast scale-up of free, online education; distance learning; and distance training of teachers via smart phones, tablets, and every other kind of device to accelerate the uptake and the quality of education in the country. All of this will require a rollout plan, a financing model, and a functional international partnership to support low-income countries. Civil society groups will play a pivotal role for SDG-based planning. They represent the needs of underrepresented communities and regions. This makes them critical partners in ensuring that SDG strategies target the needs of all segments of society and ensuring accountability for SDG implementation. They have extensive experience in delivering services to the poor and can recommend appropriate interventions in different parts of the country.

Disclaimer: The paper reflect the personal opinion of the author and are not necessarily endorsed by the Doha International Family Institute. The paper was presented at the Arab Conference on the Role of CSO and SDG in 2030 agenda organized by Qatar Foundation for Social Work, Doha, Qatar in April 2016.

\section{REFERENCES}

[1] Abdelmoneium, A 2008. Non-Governmental Organizations and the Rights of Displaced

[2] Children in Sudan. (Unpublished PhD dissertation)

[3] Clark, John 1991. Democratizing Development. The Role of Voluntary Organizations. London: Earth scan.

[4] Civil Society Organizations 2016. Wikipedia "https://en.wikipedia.org/wiki/Civil_society\#cite_notediccom-1 (accessed 2 April 2016)

[5] Farrington, John; Anthony Bebbington; Kate Wellard; David Lewis (eds) (1993). Reluctant Partners? NonGovernmental Organizations, the State and Sustainable Agricultural Development. London: Routledge.

[6] Fowler, Alan 1997. Striking a Balance. A Guide to Enhancing the Effectiveness of Non- Governmental Organizations in International Development. London: Earth scan Publication

[7] Heemst, Jan. (1982). The Role of NGOs in Development: Some Perspectives for Further Research. The Hague: ISS.

[8] Hulme, David, Michael Edwards (eds) 1997. NGOs, States and Donors Too Close for Comfort. New York: St. Martin's Press
[9] Korten, David 1991. "The Role of Non-Governmental Organizations in Development: Changing Patterns and Perspectives". In: Samuel Paul, Arturo Israel (eds). NonGovernmental Organizations and the World Bank Cooperation for Development. Washington DC: World Bank, 20-40.

[10]Lyytinen, E 2009. "A Tale of three cities: Internal Displacement, Urbanization and Humanitarian Action in Abidjan, Khartoum and Mogadishu" UNHCR. http://reliefweb.int/sites/reliefweb.int/files/resources/7D0 3CEEEF0FD150A492575DB00 210A0D-Full_Report.pdf (accessed 16 September 2015)

[11] Miller, Judy 1997. Never too Young. A Handbook for Early Years Workers. London: Save the Children.

[12] Oxfam 2007. Practicing Gender Equality in Education. http://www.ungei.org/resources/files/ProgIns_wholebook. pdf (accessed 29 March 2016).

[13] Uphoff, Norman 1993. "Grassroots Organizations and NGOs in Rural Development: Opportunities with Diminishing States and Expanding Markets". World Development, 21(4): 607-622.

[14] UNESCO 2013. Regional Fact Sheet. Education in the Arab States. http://en.unesco.org/gem-report/sites/gemreport/files/219170e.pdf (accessed 25 March 2016).

[15] UNICEF 2013 Getting Ready for School. A Child-toChild Approach strategic Framework. http://www.unicef.org/education/files/GRS_StrategicFra mework_-_UPDATED_AD_25January.pdf (accessed 22 March 2016).

[16] UNICEF 2012 School Readiness. A Conceptual Framework. http://www.unicef.org/education/files/Chil2 Child_ConceptualFramework_FINAL(1).pdf (accessed 1 April 2016).

[17]UNICEF 2013. Identifying and Promoting Good Practice in Equity and Child-Friendly Education. http://www.unicef.org/cfs/files/Identifying_and_Promotin g_Good_Practice_in_Equity_and_ChildFriendly_Education.pdf) accessed 1 April 2016).

[18] United Nations 2016. Education-United National Sustainable Development Goals. http://www.un.org/ sustainabledevelopment/education/ (accessed 22 March 2016)

[19] UNESCO 2015. A Guide for Gender Equality in Teacher Education Policy and Practices.http://unesdoc.unesco. org/images/0023/002316/231646e.pdf (accessed 24 March 2016).

[20]UNICEF 2015 Global Goals for Every Child. http://www.unicef.org/post2015/files/Global_goals_for_e very_child_2_pager_Sept_2015_pdf (accessed 2 April 2016).

[21] Van Heemst, Jan (1982). The Role of NGOs in Development. The Hague: Institute of Social Studies. 
[22] World Population Review 2014. "Sudan Population 2014”.Http://worldpopulationreview.com/countries/sudan -population/ (accessed 23 April 2015).

[23] World Fact Book 2015. "Sudan". The World Fact Book. Central Intelligence Agency and Director of Central Intelligence.

http://www.odci.gov/cia/publications/factbook/geos/su.ht ml\#Econ (accessed 15 September 2015). 